\title{
Election impasse leaves science in the dark
}

Tony Reichhardt and Paul Smaglik, Washington The deadlocked race for the US presidency, together with uncertainty over the extent of Republican control in the Senate, has left a huge question mark over who will be calling the shots in science policy in January.

The traditional scramble for key positions in the new administration - such as that of the president's science adviser, and the vacant directorship of the National Institutes of Health (NIH) - was put on hold as the campaigns of Al Gore and George W. Bush concentrated on manoeuvring to determine the final outcome of the election.

But in the House of Representatives, where Republicans will keep control by a small, as yet unspecified, margin, some committee posts are alreadybeing claimed. Sherwood Boehlert (Republican, New York), a moderate republican with a strong interest in environmental protection is widely expected to become chair of the Science Committee, which has jurisdiction over most non-biomedical research programmes. Its current chairman, Jim Sensenbrenner (Republican, Wisconsin), hopes to move on to chair the Judiciary Committee.

Most leadership positions in the House will change as a result of a new rule that requires committee chairpersons who took their position six years ago to step down. "There will be a lot of musical chairs," predicts Howard Silver, who tracks science legis- lation as executive director of the Consortium of Social Science Associations.

Some of the most influential proponents of the doubling of the NIH's budget are either retiring or considering stepping away from the fray in the new Congress. And their replacements may lack either their visibility or their zeal, lobbyists for biomedicine say.

John Porter (Republican, Illinois), chair of the House subcommittee that funds the NIH and an ally of biomedical research, is retiring and Ralph Regula (Republican, Ohio) is the leading candidate to replace him. Other contenders are Henry Bonilla (Republican, Texas) and Ernest Istook (Republican, Oklahoma).

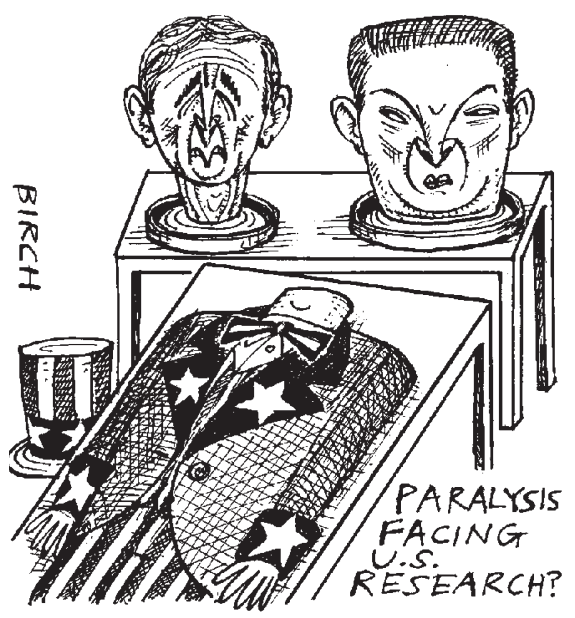

Citing dissatisfaction that the NIH budget did not come to a vote before the 2000 election, Senator Arlen Specter (Republican, Pennsylvania) has threatened to give up the chair of the Senate appropriations subcommittee that funds the agency. Specter has strongly supported the bid to double the NIH's budget in five years and is also a keen proponent of stem-cell research.

One possible successor, Senator Slade Gorton (Republican, Washington), is involved in the only Senate race that had not been called one week after the 7 November elections. The Republicans had won 50 seats and the Democrats 49, including that of Joe Lieberman (Democrat, Connecticut), Al Gore's running mate. Because Lieberman cannot sit in the Senate and be vice-president, Republicans are certain to maintain control of the chamber, albeit by a razor-thin margin.

With such an even split in numbers, bipartisanship and moderation will be needed for any legislation to survive in the 107th Congress. As Silver puts it: "Anything that looks radical is not going to pass." That should put basic research, which has strong bipartisan support, in a strong position.

But the body politic remains deeply divided along party lines on at least three science-related issues: global warming (see below), embryonic stem-cell research and national missile defence.

\section{Climate talks face uncertainty over US strategy}

The question of who will be in the White House come January will cast a heavy pall over this week's climate treaty talks in The Hague. And, ironically, some observers think that George W. Bush would be better placed than $\mathrm{Al}$ Gore to break the political stalemate in the United States on global warming.

At first glance, a Bush presidency would seem to be the environmentalists' worst nightmare. He and running mate Dick Cheney are both oilmen, and their energy strategy calls for opening up part of the protected Arctic wilderness to drilling.

Yet Bush is not as combative on these issues as many members of the Republicancontrolled Congress, and he understands that a modern politician must at least sound like an environmentalist. Early in his campaign, Bush expressed doubt about the science behind climate-change predictions, but later recanted, stating: "I believe there is global warming."

Although he opposes the Kyoto guidelines as "ineffective, inadequate and unfair to America", so do many other US politicians in both parties. The 1997 protocol, which called for sharp reductions in greenhouse-gas emissions by 2008 , was dead on arrival in Congress, and the body has not stirred since.

That leads Henry Jacoby, an environmental economist at the Massachusetts Institute of Technology's Sloan School of Management, to contend that "if you wanted to see progress on the climate issue, you would have voted for Bush. Gore has so much opposition, and is so

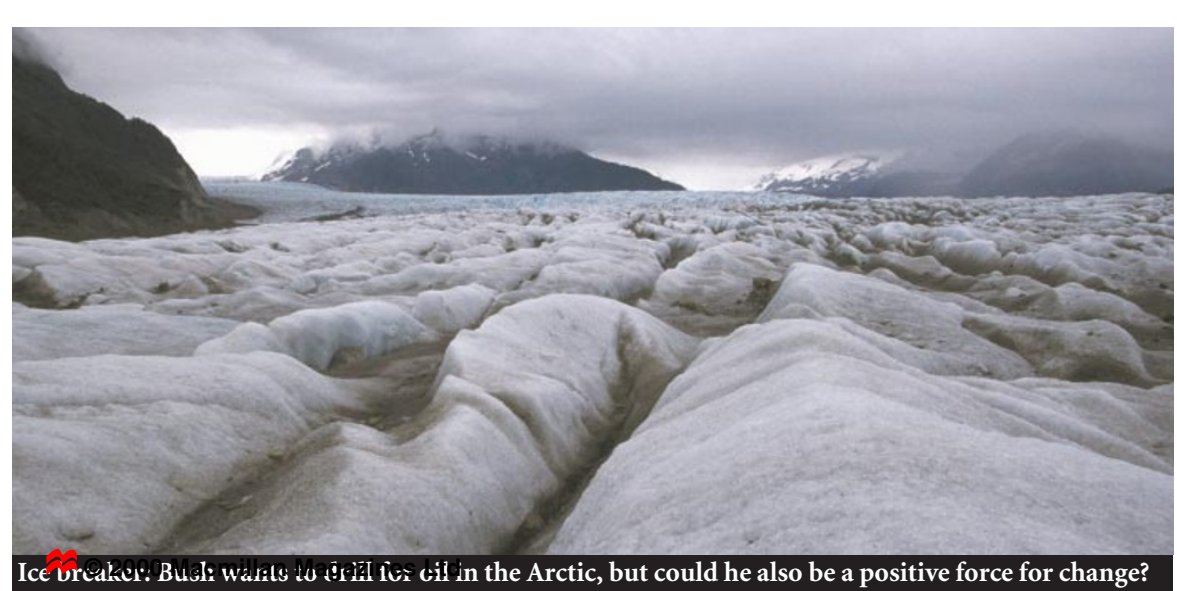

locked in to [the Kyoto] strategy" that it may not be possible for him to break the impasse.

The US delegation to the Sixth Conference of Parties to the United Nations Framework Convention on Climate Change, led by under-secretary of state Frank Loy, will represent the Clinton-Gore administration. As of early this week, Bush was not planning to send a representative to the talks. T. R. 